\title{
Ubiquitous imposex and organotin bioaccumula- tion in gastropods Nucella lapillus from Galicia (NW Spain): a possible effect of nearshore shipping
}

\author{
J. M. Ruiz*, M. Quintela, R. Barreiro \\ Depto. BA, BV y Ecología, Universidade da Coruña, Campus da Zapateira s/n, E-15071 Coruña, Spain
}

\begin{abstract}
A survey was conducted during the summer of 1996 to assess the expression, extent and impact of imposex (a set of sexual anomalies) in 37 populations of Nucella lapillus spread over the Galician coastline (NW Spain); the bioaccumulation of several organotin (OT) species (monobutyltin, MBT: dibutyltin, DBT; tributyltin, TBT; and triphenyltin, TPhT) was also determined in 20 of those samples. While imposex, TBT (from 36 to $974 \mathrm{ng} \mathrm{Sn}^{-1}$ dry weight, ppb) and DBT (from 169 to $909 \mathrm{ppb}$ ) were detected in every sample examined. MBT (from 65 to $387 \mathrm{ppb}$ ) and TPhT (from 39 to $250 \mathrm{ppb}$ ) were quantifiable in only 15 and 11 of them, respectively. imposex was found to have led to frequent female sterilisation in most of the populations of this intertidal gastropod, although none of them is considered to be at risk of extinction. This may be partially due to the observation that these specimens appear more resistant to the sterilising effect of TBT than northern congeners. Fishing and merchant fleets are thought to be the dominant sources of OT pollution within embayments, with pleasure boats being of lesser importance. In addition, the characteristic pattern of OT body residues li.e. undetectable TPhT and low TBT/(TBT+DBT) ratio] indicates that imposex in several open coast populations may stem from nearshore merchant shipping via the horizontal transport of paint leachates.
\end{abstract}

KEY WORDS: Bioaccumulation - Imposex · Galicia (NW Spain) · Nucella lapillus · Shipping · Organotin compounds . TBT

\section{INTRODUCTION}

Nucella lapillus (L.) is an intertidal carnivorous gastropod which has an Eastern Atlantic distribution ranging from northern Russia to Portugal (Crothers 1985). As is the case with many other related species, this inhabitant of rocky shores suffers from the superimposition of male sexual characteristics onto females as a response to anthropogenic pollution (i.e. imposex, see Gibbs \& Bryan 1996). Imposex in $N$. lapillus is conspicuous all over its European range (Gibbs et al. 1991) and has often resulted in population extinction through a consistent mechanism of female sterilisation (e.g. Ritsema et al. 1991, Huet et al. 1996, Minchin et al. 1997); its expression, though, is somewhat variable in southern populations possibly because of genetic differ-

•E-mail: jmruiz@udc.es ences (Gibbs \& Bryan 1996, Oehlmann et al. 1996). The causative agent of imposex is tributyltin (TBT), an organometallic compound used for over 3 decades as the biocide in many antifouling paints (e.g. Ruiz et al. 1996). Research on imposex and other environmental damage led to a widespread ban on the use of TBT paints on boats less than $25 \mathrm{~m}$ long being legislated by the late 1980s and early 1990s (CCE 1989, Stewart 1996). This regulation was devised to protect aquaculture and marine life from TBT leachates of smaller pleasure boats functioning in water bodies of restricted renewal, while the risk posed by larger merchant and fishing vessels was supposed to be eliminated through dilution. After several years, the ban seems to have been effective since, for instance, a number of populations of $N$. lapillus and other gastropods under the influence of marinas are recovering from the symptoms and/or effects of imposex. (Minchin et al. 1995 


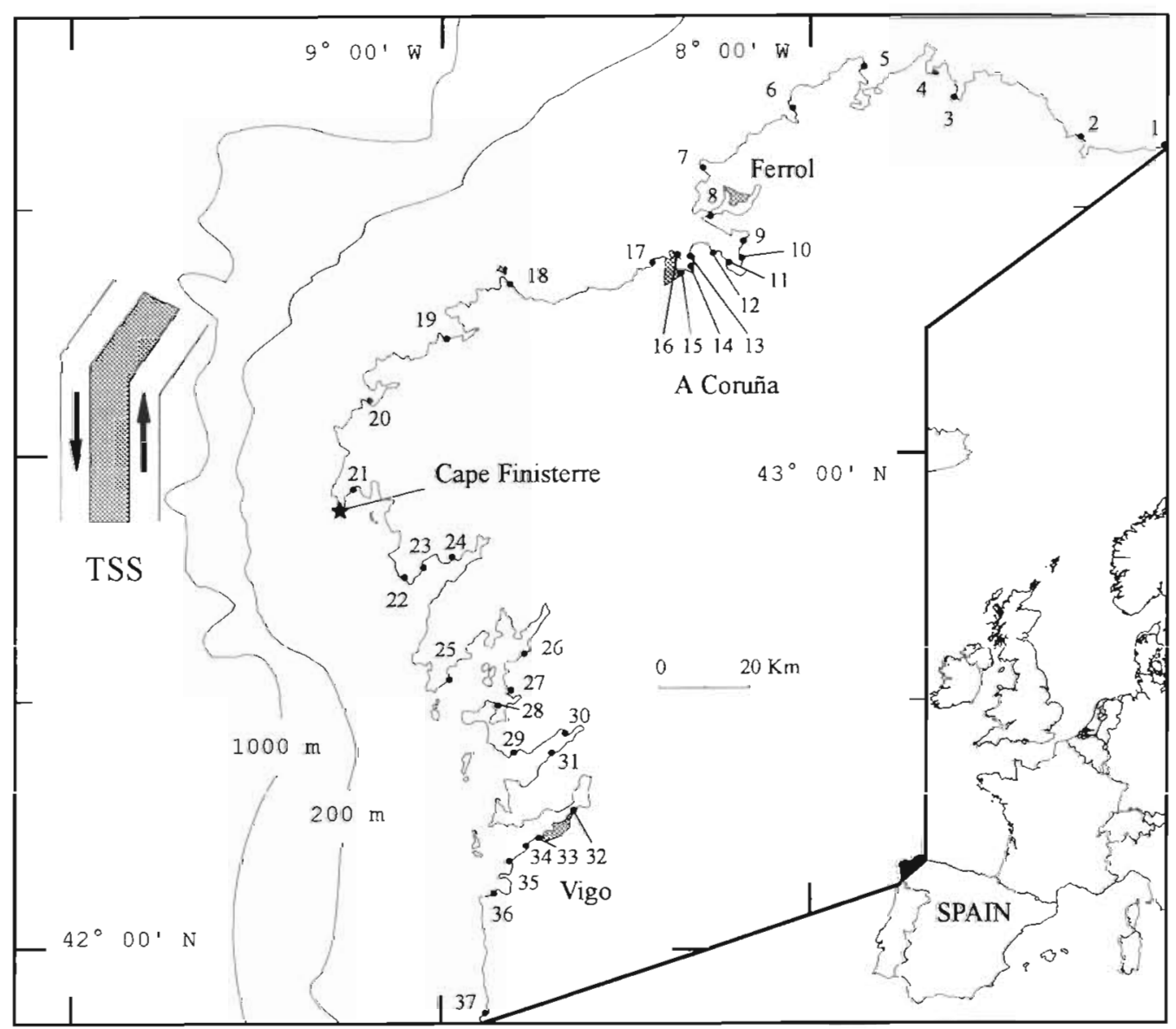

Fig. 1. Nucella lapillus in Galicia 1996. Location of sampling sites and extent of the IMO's Traffic Separation Scheme (TSS, see text for further details)

Tester \& Ellis 1995, Evans et al. 1996, Gibbs \& Bryan 1996. Smith 1996). The possible failure to respect the current ban (e.g. Huet et al. 1996) is a separate question. However, the debate on TBT impact and legislation continues (e.g. de Mora 1996), since there is increasing evidence that the painting of larger vessels is of more environmental concern than previously envisaged. This applies to protected ports and surrounding areas (Smith 1996, Harding et al. 1997. Minchin et al. 1997) as well as to of fshore waters (Iwata et al. 1994, Yamada et al. 1997) and bottoms (Ten Hallers-Tjabbes et al. 1994, Ide et al. 1997).

Galicia is a strongly sea-oriented area in NW Spain. For instance, its annual mussel yield exceeds that of The Netherlands (the 3rd largest world producer), and it hosts more than 9000 fishing boats (i.e. $9 \%$ of the European Union fleet; Anonymous 1997). The high productivity of its waters is largely due to nutrient upwelling off Cape Finisterre, a seasonal event which influences most of the $1720 \mathrm{~km}$ long coastline (e.g. Prego \& Bao 1997). This upwelling interacts with the irregular littoral configuration, the shifting wind fields and the varying estuarine runoff to result in a complex oceanic circulation pattern over the narrow continental shelf (McClain et al. 1986, Tenore et al. 1995). As a result of it all, nearshore waters are thoroughly mixed (R. Prego pers. comm.). Because of its geographical situation, the Galician coast is also traditionally approached by an intense shipping traffic routing in and out of Northern European ports. An estimated commercial fleet of 50000 vessels goes annually through a Traffic Separation Scheme (TSS) set by the International Maritime Organisation around 26.4 nautical miles (NM) offshore (J. Pose, Finisterre Maritime Safety Centre, pers. comm.). Prior to May 1994, the TSS was $11.5 \mathrm{NM}$ closer to the coast, i.e. between the 1000 and $200 \mathrm{~m}$ isobaths (Fig. 1). Only $5 \%$ of this traffic enters Galician ports, mainly in the industrial bays of A Coruña, Ferrol and Vigo (Anonymous 1996). Converse to this notable merchant and offshore fishing traffic, pleasure boats manoeuvring mostly within embayments are not common, with only 10000 units registered in the area (Vales 1996). This contrasts markedly with yachting popularity in neighbouring 
countries; for instance, a 15000 pleasure boat flotilla operated out of Arcachon (a $156 \mathrm{~km}^{2}$ bay in $\mathrm{SW}$ France) in 1981/82 (Ruiz et al. 1996).

Nucella lapillus is abundantly distributed in Galicia, and a preliminary 1987 survey found that imposex was evident in several sites around A Coruña and Vigo (Peña \& Kendall 1989). However, this restricted data set does not appear to meet today's need for scientific knowledge on the TBT subject, particularly considering the valuable information that could be obtained from the study of an area showing the rare pattern of shipping activity described above. Therefore, the present study investigated: (1) the expression of imposex in $N$. lapillus throughout the Galician coast; $(2)$ its postban spread, intensity and population impact; (3) its relationship with the organotins bioaccumulated in tissues; and (4) the sources of these residues, namely whether some of them could possibly be ascribed to offshore shipping. In order to accomplish the last 2 objectives, a modern analytical protocol able to positively characterise organotin chemical speciation was used.

\section{MATERIALS AND METHODS}

Imposex assessment. Thirty-seven sites distributed throughout the coastline were visited during the summer (July-September) of 1996; their location is shown in Fig. 1 and their Universal Transverse Mercator (UTM) co-ordinates are given in Table 1. Following as far as possible the procedures detailed by Gibbs et al. (1987), samples consisted of 30 of the largest toothed (i.e. adult) individuals. After breaking their shells with a vice in the laboratory, individuals were sexed, dissected and studied under a stereo microscope; evidently parasitised specimens were discarded. Penis length was measured to the nearest $0.01 \mathrm{~mm}$ with digital callipers, and female genitalia were closely examined. Finally, opercula were removed and each sex was pooled per site in vials that were kept frozen until chemical analysis (see below).

There are several indexes to characterise imposex intensity (Gibbs \& Bryan 1996, Stroben et al. 1996). We have used those 2 most widely employed for Nucella lapillus populations (Gibbs et al. 1987): the Relative Penis Size Index (RPSI) and the Vas Deference Sequence Index (VDSI). The RPSI expresses the bulk of female penis as a percentage of that of males $[100 \times$ (mean length of female penis) ${ }^{3} /$ (mean length of male penis) ${ }^{3}$. While its applicability to populations exhibiting seasonal penis length variation has been questioned (Stroben et al. 1996), it is acknowledged that, as in many other environmental biomonitoring exercises, the collection of samples at the same time avoids possible seasonal interferences (Minchin et al. 1997). The VDS leading to sterilisation recognises 6 distinct stages in the development of male structures on females, and the index is the average value. However, while in the UK this VDS follows a single course, $N$. lapillus in France displays 2 additional ones, notably a penisless or aphallic route (Oehlmann et al. 1996). Since the consideration of aphallic individuals for the calculation of the indexes above leads to TBT pollution underestimation (Huet et al. 1996, Stroben et al. 1996), the 73 such specimens found in our samples (i.e. $0.66 \%$ of total) were omitted from the present survey; they will be dealt with elsewhere. Finally, the proportion of sterilised females (i.e. VDS stage 5 to 6 ) in the sample was also established because of its straightforward ecological significance (see Harding et al. 1997, Minchin et al. 1997).

Organotin (OT) analysis. The concentration of OT species (monobutyltin, MBT; dibutyltin, DBT; tributyltin, TBT; and triphenyltin, TPhT) in whole tissues of pooled females was determined for 20 sites selected to include the widest range of RPSI and VDSI values. The analyses were performed in a blind manner by the LPPM (URA-CNRS 348, Université de Bordeaux I, France), a laboratory routinely participating in the production of OT Certified Reference Materials (CRM) for the EU's Bureau of Community References (BCR). The protocol used (rendering a quantification limit of around $3 \mathrm{ng} \mathrm{Sn} \mathrm{g}^{-1}$ fresh weight) followed that detailed by Szpunar et al. (1996). In summary, samples were thawed and homogenated following courier delivery. Four $0.3 \mathrm{~g}$ aliquots were weighed, 3 of them for replicate analyses and another 1 for dry weight determination. Tripropyltin was added as an internal standard and the sample was solubilised with tetramethylammonium hydroxide (TMAH) in a low power microwave (Microdigest A301, Prolabo) field. After adjusting the $\mathrm{pH}$ to 5 , the OTs were ethylated using a $1 \%(\mathrm{w} / \mathrm{v})$ solution of sodium tetraethylborate $\left(\mathrm{NaBEt}_{4}\right)$, and then extracted to isooctane. This organic phase was injected in a GC-AED system (Gas Chromatograph with Atomic Emission Detector; HP 6890 and HP G2350A) by means of an automatic sampler. The procedure was validated using 2 CRMs: the Japanese NIES1 1 fish tissue [certified TBT content $=1.3 \pm 0.1 \mu \mathrm{g} \mathrm{g}^{-1}$ dry weight (DW), reference $\mathrm{TPhT}$ value $\left.=6.3 \mu \mathrm{g} \mathrm{g}^{-1} \mathrm{DW}\right]$ and another animal tissue currently under certification by the BCR. The result of the former was $1.25 \mathrm{\mu g} \mathrm{g}^{-1}$ DW for TBT and $5.81 \pm 0.81 \mathrm{\mu g} \mathrm{g}^{-1} \mathrm{DW}$ for TPhT, and that of the latter also fell within acceptable limits (official range still confidential). The concentration obtained for every OT is reported here as mean $\mathrm{ng} \operatorname{Sn} \mathrm{g}^{-1} \mathrm{DW}$ (ppb).

The normal distribution of imposex and OT data sets was checked prior to establishing the statistical relationships among them; the significance levels are depicted below as $\cdots$ and $\cdots$, respectively, for $p<$ 0.001 and $\mathrm{p}<0.01$ 


\section{RESULTS}

\section{Imposex levels}

All Nucella lapillus populations investigated in the Galician coast were found to be affected by imposex (Table 1). Values for RPSI, VDSI and \% sterilisation ranged from 6 to 59 , from 3.2 to 4.6 and from 0 to 54 , respectively. The correlation between $\%$ sterilisation and RPSI (Fig. 2, $r=0.73 \cdots$ ) was the weakest of those that could be established between any pair of these 3 data sets. Lowest imposex indexes (e.g. RPSI $\leq 10$ ) were shown by samples from the exposed shores of the northern coast (Sites 1, 2,7,17 and 18); highest values (e.g. RPSI > 35) were displayed by those collected within in- dustrial bays (Sites 8, 13-15, 32 and 33), and also by some populations inhabiting the sheltered reaches of mussel-culturing southern estuaries (e.g. Site 24).

\section{Imposex versus TBT}

Every imposex index depended logarithmically on the concentration of TBT in female tissues (see Fig. 3 for RPSI), with correlation coefficients close to $0.80^{\cdots}$. In no case was the relationship improved by relating the indexes to the residues of other OTs, nor by pooling together TBT plus any combination of the other compounds. Thus, the geographical pattern of TBT residues generally agrees with that of imposex values:

Table 1. Nucella lapillus in Galicia 1996. Results of the survey, including site, code and UTM co-ordinates of the populations studied, their values for imposex indexes, the percentage of sterilised females in the sample ( $\%$ st), and their mean female organotin concentrations (ng Sn $\mathrm{y}^{-1} \mathrm{DW}$ ). See text for further details. nq: not quantifiable

\begin{tabular}{|c|c|c|c|c|c|c|c|c|c|}
\hline Site & Code & UTM & RPSI & VDSI & $\%$ st & MBT & $\mathrm{DBT}$ & TBT & TPhT \\
\hline Kibadeo & $i$ & $29 \bar{Y} \bar{P} j 58 \overline{+} \mathrm{Z} 4 \mathrm{U}$ & $\bar{y}$ & 3.2 & 0 & $\mathrm{nq}$ & $243^{2}$ & $51^{b}$ & $\mathrm{nq}$ \\
\hline Foz & 2 & 29TPJ4 10267 & 10 & 4.2 & 18 & & & & \\
\hline Viveiro & 3 & 29TPJ 119372 & 45 & 4.2 & 23 & & & & \\
\hline Barqueiro & 4 & 29TPJ065433 & 33 & 4.3 & 25 & & & & \\
\hline Cariño & 5 & 29TNJ914443 & 19 & 4.2 & 16 & $\mathrm{nq}$ & $251^{\mathrm{d}}$ & $151^{c}$ & $\mathrm{nq}$ \\
\hline Cedeira & 6 & 29TNJ750344 & 21 & 4.1 & 7 & & & & \\
\hline Prior & 7 & 29TNJ564216 & 9 & 3.2 & 3 & & & & \\
\hline Mugardos & 8 & 29TNJ591128 & 45 & 4.3 & 33 & $337^{\mathrm{b}}$ & $909^{d}$ & $702^{b}$ & $250^{\mathrm{b}}$ \\
\hline Centroña & 9 & 29TNJ652070 & 24 & 4.0 & 1.7 & $1.28^{d}$ & $346^{b}$ & $244^{\mathrm{d}}$ & $93^{c}$ \\
\hline Perbes & 10 & 29TNJ636029 & 13 & 3.9 & 11 & & & & \\
\hline Sada & 11 & 29TNJ610012 & 37 & 4.1 & 10 & & & & \\
\hline Veigue & 12 & 29 TNJ 573040 & 22 & 4.1 & 9 & & & & \\
\hline Mera & 13 & 29 TNJ522037 & 37 & 4.2 & 25 & $387^{c}$ & $777^{\mathrm{c}}$ & $705^{c}$ & $165^{\circ}$ \\
\hline Bastiagueiro & 14 & 29TNH520994 & 59 & 4.5 & 40 & $329^{\prime}$ & $589^{b}$ & $555^{e}$ & $149^{\circ}$ \\
\hline Sta. Cristina & 15 & 29TNH509992 & 51 & 4.5 & 46 & $334^{b}$ & $735^{\mathrm{a}}$ & $786^{d}$ & $198^{\mathrm{b}}$ \\
\hline Dique & 16 & 29 TNJ500022 & 21 & 4.1 & 21 & $176^{\mathrm{e}}$ & $359^{\mathrm{h}}$ & $321^{c}$ & nq \\
\hline Langosteira & 17 & 29TNJ417012 & 7 & 3.3 & 0 & $\mathrm{nq}$ & $244^{\mathrm{c}}$ & $79^{a}$ & nq \\
\hline Malpica & 18 & 29TNH159970 & 6 & 3.6 & 0 & $76^{1}$ & $189^{d}$ & $36^{b}$ & $\mathrm{nq}$ \\
\hline Laxe & 19 & 29TNH008852 & 32 & 4.1 & 9 & & & & \\
\hline Muxía & 20 & 29TMH 1832724 & 33 & 4.2 & 26 & & & & \\
\hline Corcubión & 21 & 29TMH821547 & 18 & 4.3 & 28 & $65^{\mathrm{h}}$ & $169^{b}$ & $53^{e}$ & nq \\
\hline Louro & 22 & 29TMH908342 & 18 & 3.9 & 6 & & & & \\
\hline Muros & 23 & 29TMH958373 & 38 & 4.3 & 28 & & & & \\
\hline Creo & 24 & 29TNH019374 & 57 & 4.6 & 54 & $172^{d}$ & $649^{a}$ & $974^{b}$ & $\mathrm{nq}$ \\
\hline Ribeira & 25 & 29TNH012113 & 39 & 4.3 & 29 & $134^{b}$ & $430^{c}$ & $280^{b}$ & $n q$ \\
\hline Vilagarcía & 26 & 29TNH181160 & 28 & 4.5 & 44 & $129^{e}$ & $460^{\lrcorner}$ & $437^{d}$ & $55^{c}$ \\
\hline Cambados & 27 & 29TNH142072 & 18 & 4.0 & 15 & & & & \\
\hline A Toxa & 28 & 29TNH12804 1 & 43 & 4.3 & 33 & $77^{\mathrm{d}}$ & $331^{c}$ & $224^{d}$ & $\mathrm{nq}$ \\
\hline Sanxenxo & 29 & 29TNG153943 & 28 & 3.8 & 11 & & & & \\
\hline Poio & 30 & 29 TNC259976 & 30 & 4.5 & 50 & $178^{\circ}$ & $418^{b}$ & $421^{\circ}$ & $110^{\mathrm{b}}$ \\
\hline Marín & 31 & 29TNG233933 & 41 & 4.3 & 40 & & & & \\
\hline Rande & 32 & 29TNG280813 & 47 & 4.6 & 53 & $113^{i}$ & $420^{b}$ & $521^{\mathrm{C}}$ & $69^{\circ}$ \\
\hline Bouzas & 33 & 29TNG280813 & 36 & 4.4 & 36 & $199^{\prime \prime}$ & 571 & $454^{c}$ & $157^{\mathrm{b}}$ \\
\hline Samil & 34 & 29TNG184742 & 41 & 3.5 & 10 & $\mathrm{nq}$ & $322^{4}$ & $112^{e}$ & $58^{c}$ \\
\hline Canido & 35 & 29TNG169748 & 32 & 4.3 & 29 & & & & \\
\hline Baiona & 36 & 29TNG123636 & 35 & 4.0 & 6 & & & & \\
\hline A Garda & 37 & 29TNG103390 & 43 & 4.4 & 46 & $\mathrm{nq}$ & $273^{d}$ & $340^{\mathrm{b}}$ & 39 \\
\hline
\end{tabular}




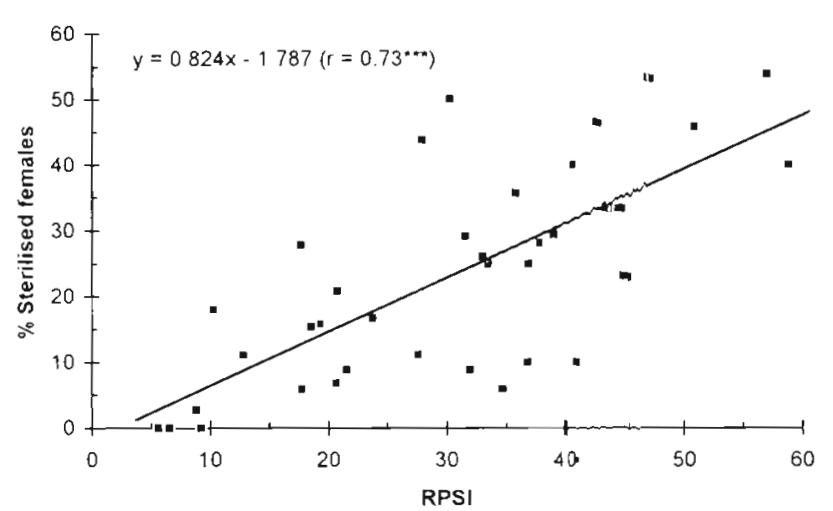

Fig. 2. Nucella lapillus in Galicia 1996. Pal w o sterilised females versus Relative Penis Size Irodex

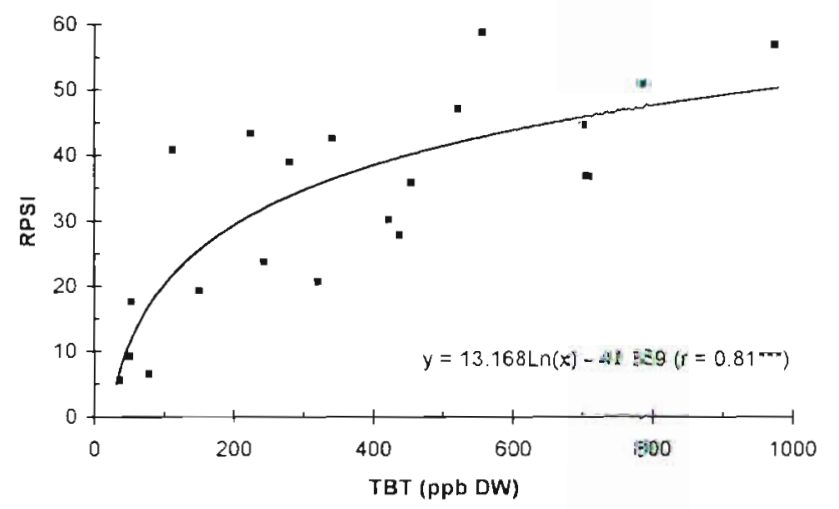

Fig. 3. Nucella lapillus in Galicia 1996. Plot ad Eelative Penis Size Index versus TBT

lowest (below $80 \mathrm{ppb}$ ) in samples from the open northern coast (Sites 1, 17, 18 and 21), and highest (above $450 \mathrm{ppb}$ ) in those within industrial bays (5 tes $8,13-15$, 32 and 33).

\section{Organotin residues}

OT concentrations found in female tissues are shown in Table 1. Their total ranged from 288.22198 ppb. TBT and DBT were ubiquitous in all 20 gittes, spanning from 36 to 974 and from 169 to 909 pplin. nespectively. MBT (range from 65 to $387 \mathrm{ppb}$ ) was gountifiable in most of the samples examined, and TPhT mly in half of them (range from 39 to $250 \mathrm{ppb}$ ). A linean correlation could be established between TBT and enrery other OT. $\operatorname{MBT}(\mathrm{r}=0.71 \cdots)$, DBT $(\mathrm{r}=0.89 \cdots)$ and $\mathrm{TPhT}(\mathrm{r}=$ $\left.0.77^{\cdots}\right)$. Where present, TPhT was a variatule and independent fraction of TBT (Fig. 4). The arcentage of TBT with respect to the aggregate TBT - DBBT was also wide-ranging (from 16 to 60 ), but incrused with the concentration of TBT (Fig 5, r =0.93 *')

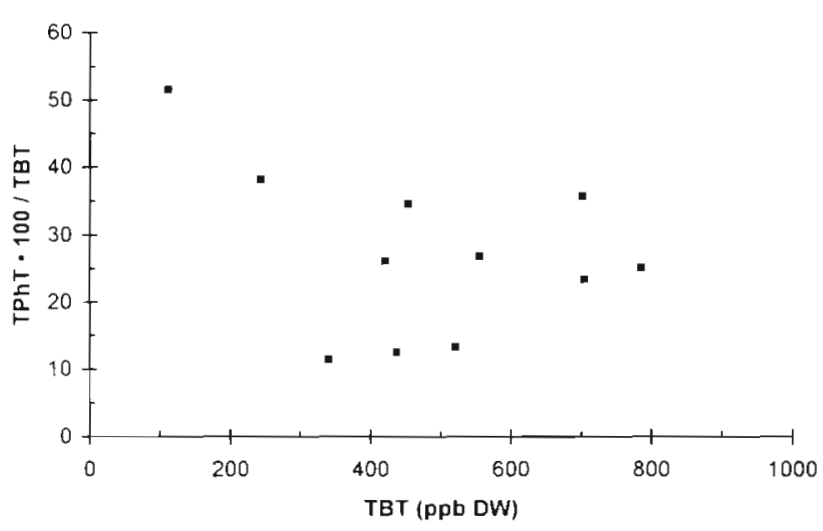

Fig. 4. Nucella lapillus in Galicia 1996. Plot of TPhT/TBT ratio versus TBT

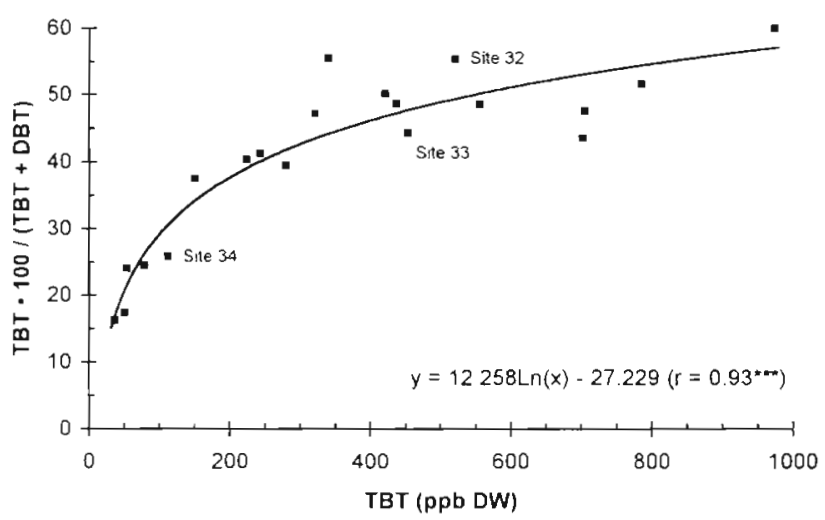

Fig. 5. Nucella lapillus in Galicia 1996. Plot of TBT/(TBT + $\mathrm{DBT}$ ) ratio versus TBT

\section{DISCUSSION}

\section{Imposex levels and their environmental implications}

It is well established that imposex in populations of Nucella lapillus is specifically caused by TBT (e.g. Gibbs \& Bryan 1996). The present work confirms that its assessment is a reliable technique for the bioindication of TBT pollution even over long and diverse coastlines. The results give evidence that the whole Galician coast is contaminated by TBT concentrations resulting in biological effects, and complete a detailed database showing that imposex is conspicuous throughout the European range of this gastropod, from Iceland (Svavarsson \& Skarphedinsdottir 1995) to Scotland and S England (e.g. Gibbs et al. 1991), France (e.g. Huet et al. 1996) and, now, Spain. In addition, most samples included female individuals effectively sterilised by TBT (see Table 1), although no current population is considered to be at risk of extinction since even the worst affected ones showed a proportion of functional females of around $50 \%$. In a first 
instance, this would seem in fortunate contrast with studies reporting that the species has been wiped off considerable shoreline stretches elsewhere: UK (Gibbs \& Bryan 1996), Ireland (Minchin et al. 1997), The Netherlands (Ritsema et al. 1991) and France (Huet et al. 1996). From a literature review, however, it is clear that at least a few populations within this area (1 opposite our Site 15 and 2 upstream of Site 8 ) have indeed disappeared between the 1960s and 1990s. As for the time evolution of imposex, we can relate our $N$. lapillus RPSI data to those similarly obtained by Peña \& Kendall (1989) from a summer 1987 survey. For this comparison to be significant, only those sites sampled 9 yr apart and where we have not found any aphallic individuals are considered (i.e. our Sites 13, 17, 32 and 36): all RPSI values in 1996 are higher (1.6-, 1.8-, 3.1-, and 1.1-fold, respectively) than in 1987 . This is a clear indication that the directive regulating the use of TBT paints (CCE 1989) has not been efiective in reducing OT contamination over the Galician coast, thereby suggesting that the local TBT sources are mainly larger merchant and fishing vessels escaping current legislation.

\section{Imposex versus TBT: differential sensitivity of local populations?}

Although Harding et al. (1997) found a relationship between \% sterilisation and RPSI similar to that displayed in Fig. 2, their slope is steeper than ours. Thus, Scottish Nucella lapillus populations with an RPSI of 40 showed more than $70 \%$ of their females with a blocked vulva (i.e. unable to lay egg capsules), whereas the corresponding value for that RPSI in Galicia is only $30 \%$ sterilisation. Furthermore, while the correlation of RPSI versus TBT female residues (Fig. 3) is of a shape very much like that found for SW England $N$. lapillus (Fig. 9A in Gibbs et al. 1987), there is an interesting difference between both data sets: the RPSI value reached by females containing TBT at $400 \mathrm{ppb}$ is above 60 in UK versus one around 40 in Galicia; for females similarly contaminated, a disagreement of nearly 1 VDSI unit can be gathered from comparing their Fig. 9B to the data in Table 1. Gibbs et al. (1991) showed that the level of sensitivity and development of $N$. lapillus imposex as a response to TBT pollution is uniform throughout the UK (from the Shetlands to SW England), but it has recently been argued that the high variability that can be observed in the expression of imposex in this gastropod in the southern reaches of its European range is based on genetic differences (Gibbs \& Bryan 1996, Oehlmann et al. 1996). The results above thus provide novel grounds for suspecting differential sensitivity to TBT of meridional populations.
One alternative contention to this bioaccumulation evidence is that analytical differences could account for the conflict. However, it can probably be ruled out in view of the findings of Minchin et al. (1997) using modern protocols validated bi Certified Reference Materials: in 4 out of 5 Irish $v$ lapillus populations contaminated at 500 to $700 \mathrm{ppb}$ TET DW, $100 \%$ of the females showed a blocked vulva. This contrasts so markedly with the proportion of sterilisation we found in similarly contaminated femailes (below $50 \%$, see Table 1 ) that the matter certanly warrants further investigation.

\section{Organotin residues and their sources}

No data on tissue TPh I are known for Nucella lapillus, nor can we speculate on its metabolism since the microwave used in tha analyticai protocoi breaks the labile phenyl-Sn bonds of both di- and monophenyltin. Still, some interesting insights can be obtained from comparing our data with those pertaining to other related camizorous gastropods, particularly if attention is paid to the fact that TPhT is more hydrophobic than TBT (and therefore binds to particulate matter to a large extent, e.g. Tolosa et al. 1992). Thus, Mensink et al. (1996) found that phenyltin residues were higher than butyltins in Dutch sediment-dwelling whelks le.g. 92 and $12 \mathrm{ppb}$, respectively for TPhT and TBTl; the same holds for the Japanese rock shell (Horiguchi et al. 1994), a species showing marked potential for sediment contamination monitoring (Han et al 1996). The apparent contrast of these 2 reports with the present data (remember $N$. lapillus inhabits only rocky bottoms) reinforces the conclusion of Stäb et al. 1996) that TPhT residues are higher than TBTs in enmals living in or near to the sediment. As for its sources. TPhT is the only OT used as a fungicide for crop protection, can be transported in considerable quant ties via the atmosphere and is added in low proportions $<10 \%$ of TBT) as a co-toxicant to some long-performance antifouling paints (Stäb et al. 1995, 1996). Such paints are overwhelmingly applied to small pleasure boats and, according to the literature, this results in a pattern of triorganotin occurrence: mussels from a marina contained both TBT and TPhT (3516 and $311 \mathrm{ppb}$, respectively) while those collected within Barcelona commercial harbour accumulated considerable TBT but no TPhT (Morcillo et al. 1997)i similarly, subsurface waters from the Cote d'Azur were contaminated by both compounds if collected in marinas (mean of 37 and $4.5 \mathrm{ng} \mathrm{Sn} \mathrm{l}^{-1}$, respectively, for TBT and TPhT) whereas most port samples contained higher TBT but undetectable TPhT (Tolosa et al. 1996). It appears then that 
these 2 triorganotins are expected to coexist in areas where pleasure boats constitute a substantial source of OT (TPhT being a small fraction of TBT) while only TBT is to be found where larger merchant and fishing vessels predominate. This pattern generally agrees with our data in that both TBT and TPhT occurred in samples within embayments while the latter was not detected in those from the open coast. In addition, the high proportion of TPhT 25 to $50 \%$ of the TBT residue, see Fig. 4) in most samples where both organometals have been detected probably indicates that other activities such as diverse crops (TPhT is used world-wide as a fungicide in agriculture) and industries contribute to the environmental TPhT load (see Stäb et al. 1995); the variability in location and intensity of these additional sources would prevent the TPhT fraction from being related to TBT.

The persistence of TBT in marine waters is short, with degradation mainly involving successive debutylation to DBT and $\mathrm{MBT}$; its typical half-life ranges from $1 \mathrm{wk}$ in estuaries to $2-3 \mathrm{wk}$ in open ocean waters (see review by Batley 1996). On the one hand, this results in water samples usually showing a positive correlation for either derivative versus the parent compound, which indicates a common origin for all 3 butyltins (e.g. Seligman et al. 1996). Since Bryan et al. (1989) showed that the TBT body burden of Nucella lapillus is accumulated mostly from water rather than from food, our correlations between TBT and the other butyltins agree with that general rule. Deviations probably stem from the variable OT metabolism of this predator gastropod and, possibly, its prey (mostly mussels and/or barnacles). This metabolism is indeed mutable at least for $N$. lapillus, for field and laboratory data showed that TBT concentration factors at high sea water contamination levels (107 ng Sn $\mathrm{l}^{-1}$ ) are only one third of the values typical for ambient concentrations 1 order of magnitude lower (Bryan et al. 1987); this drop was ascribed to accelerated degradation of TBT by the tissues, and it is thought that such a detoxifying mechanism may also account for the curvilinear shape of Fig. 5. On the other hand, these TBT features above allow the relative proportion of TBT and DBT in water samples (expressed as a percentage of their aggregate or as their ratio) to be used as a marker of proximity to pollution sources (e.g. Seligman et al. 1996) or, in other words, freshness of contaminant inputs (e.g. Tolosa et al. 1996). Differences in exposure of biota can also be inferred from this sort of relative index when butyltin speciation is applied to samples encompassing a wide range of environmental scenarios. For instance, based on the positive relation between. TBT/DBT and TBT they found while working with freshwater mussels throughout The Netherlands, Stäb et al. (1995) pro- posed that sites with low TBT/DBT ratios are not near sources and are characterised by low TBT residues in tissues. This reasoning firstly explains the negative gradient observed in Vigo (Site 32 down to 34, see Fig. 5), an estuary where, as usual, industrial activities releasing TBT (shipyards, dry docks, etc.) tend to concentrate in the more protected upper reaches. And, secondly, it indicates that OT contamination in open coast sites where TBT is around $20 \%$ of aggregate TBT + DBT originates from a distant source.

\section{Conclusions}

It has been found that the populations of Nucella lapillus throughout the Galician coast are affected by imposex; the local expression of this consequence of TBT contamination resembles more closely the variable phenomenon observed in France than the consistent anomaly characteristic of northern latitudes. Imposex has led to frequent female sterilisation in most of the populations, but none of them is feared to be at risk of disappearance. This may bear some relationship with the observation that the TBT body residues determined result in a sterilising effect which is less intense than in northern populations. Since pleasure boating is of limited popularity in the area, the main source of O'T pollution is likely to be the considerable number of larger commercial and fishing vessels entering embayments. However, there are some patterns of OT bioaccumulation (i.e. undetectable TPhT and low proportion of TBT in tissues) suggesting that imposex in several open coast populations stems from nearshore merchant shipping via the horizontal transport of paint leachates.

Acknowledgements. This work was partially funded by the Xunta de Galicia (Project XUGA 10301A96).

\section{LITERATURE CITED}

Anonymous (1996) 1995 annual report. La Coruña's Port Authority, A Coruña

Anonymous (1997) Special issue on the World Fishing Exhibition, Vigo97. La Voz de Galicia 17/IX/97:1-64 (in Spanish)

Batley $G$ (1996) The distribution and fate of tributyltin in the marine environment. In: de Mora SJ (ed) Tributyltin: case study of an environmental contaminant. Cambridge University Press, Cambridge, p 139-166

Bryan GW, Gibbs PE, Burt GR, Hummerstone LG (1987) The effects of tributyltin (TBT) accumulation on adult dogwhelks, Nucella lapillus: long-term field and laboratory experiments. J Mar Biol Assoc UK 67:525-544

Bryan GW, Gibbs PE, Hummerstone LG, Burt GR (1989) Uptake and transformation of ${ }^{14} \mathrm{C}$-labelled tributyltin chloride by the dog-whelk, Nucela lapillus: importance of absorption from the diet. Mar Environ Res 28:241-245

CCE (1989) Directive du Conseil 89/677/CCE. J Off Comm Eur L. 398/19:19-23 
Crothers JH (1985) Dog-whelks: an introduction to the biology of Nucella lapillus (L.). Field Stud 6:291-360

de Mora SJ (ed) (1996) Tributyltin: case study of an environmental contaminant. In: Campbell PGC, Galloway JN, Harrison RM (eds) Cambridge Environmental Chemistry Series No. 8. Cambridge University Press, Cambridge

Evans SM, Evans PM, Leksono T (1996) Widespread recovery of dogwhelks, Nucella lapillus (L.), from tributyltin contamination in the North Sea and Clyde Sea. Mar Pollut Bull 32:263-269

Gibbs PE, Bryan GW (1996) TBT-induced imposex in neogastropod snails: masculinization to mass extinction. In: de Mora SJ (ed) Tributyltin: case study of an environmental contaminant. Cambridge University Press, Cambridge, $p$ $212-236$

Gibbs PE, Bryan GW, Pascoe PL (1991) TBT-induced imposex in the dog-whelk. Nucella lapillus: geographical uniformity of the response and effects. Mar Environ Res 32: $79-87$

Gibbs PE, Bryan GW. Pascoe PL, Burt GR (1987) The use of the dog-whelk, Nucella lapillus, as an indicator of tributyltin (TBT) contamination. J Mar Biol Assoc UK 67:507-523

Han BC, Jeng WL, Hung TC, Wen MY (1996) Relationship between copper speciation in sediments and bioaccumulation by marine bivalves of Taiwan. Environ Pollut 91:35-39

Harding MJC, Rodger GK, Davies IM, Moore JJ (1997) Partial recovery of the dog-whelk (Nucella lapillus) in Sullom Voe, shetland trom tributyltin contamination. Mar Environ Res 44:285-304

Horiguchi T, Shiraishi H, Shimuzu M, Morita M (1994) Imposex and organotin compounds in Thais clavigera and. $T$ bronni in Japan. J Mar Biol Assoc UK 74:651-669

Huet M, Paulet YM, Glemarec M (1996) Tributyltin (TBT) pollution in the coastal waters of west Brittany as indicated by imposex in Nucella lapillus. Mar Environ Res 41:157-167

Ide I, Witten EP, Fischer J, Kalbfus W, Zellner A, Stroben E, Watermann B (1997) Accumulation of organotin compounds in the common whelk Buccinum undatum and the red whelk Neptunea antiqua in association with imposex. Mar Ecol Prog Ser 152:197-203

Iwata H, Tanabe S, Miyazaki N, Tatsukawa R (1994) Detection of butyltin compounds residues in the blubber of marine mammals. Mar Poljut Bull 28:607-612

McClain CR, Chao SY, Atkinson LP, Blanton JO, Castillejo F (1.986) Wind-driven upwelling in the vicinity of Cape Fin.isterre, Spain. J Geophys Res 91:8470-8486

Mensink BP, Ten Hallers-Tjabbes CC, Kralt J, Freriks IL Boon JP (1996) Assessment of imposex in the common whelk, Buccinum undatum (L.) from the Eastern Scheldt, The Netherlands. Mar Environ Res 41:315-325

Minchin D, Bauer B, Oehlmann J, Schulte-Oehlmann U, Duggan CB (1997) Biological indicators used to map organotin contamination from a fishing port, Killybegs, Ireland. Mar Pollut Bull 34:235-243

Minchin D, Oehlmann J, Duggan CB, Stroben E, Keatinge M (1.995) Marine TBT antifouling contamination in Ireland, following legislation in 1987 Mar Pollut Bull 30:633-639

Morcillo Y, Borghi V, Porte C (1997) Survey of organotin compounds in the western Mediterranean using molluscs and fish as sentinel organisms. Arch Environ Contam Toxicol 32:198-203

Oehlmann J, Stroben E, Fioroni P (1996) New facts about TBT-induced imposex in prosobranchs: general aspects. Malacol Rev Suppl 6 (Mollusc Reprod):149-156

Peña J. Kendall M (1989) Imposex en Nucella lapillus como indicador de contaminacion por TBT en el norte de la Peninsula Iberica. Bentos 6:455-463
Prego R, Bao R (1997) Upwelling influence in the Galician coast: silicate in shelf water and underlying surface sediments. Cont Shelf Res 17:307-318

Ritsema R, Laane RWPM, Donard OFX (1991) Butyltins in marine waters of The Netherlands in 1988 and 1989: concentrations and effects. Mar Environ Res 32:243-260

Ruiz JM, Bachelet G, Caumette P, Donard OFX (1996) Three decades of tributyltin in the coastal environment with emphasis on Arcachon Bay, France. Environ Pollut 90:195-203

Seligman PF, Maguire RJ, Lee RF, Hinga KR, Valkirs AO, Stang PM (1996) Persistence and fate of tributyltin in aquatic ecosystems. In: Champ MA, Seligman PF (eds) Organotin: environmental fate and effects. Chapman \& Hall, London, p 429-457

Smith PJ (1996) Selective decline in imposex levels in the dogwhelk Lepsiella scobina following a ban on the use of TBT antifoulants in New Zealand. Mar Pollut Bull 32: 362-365

Stäb JA, Frenay M, Freriks IL, Brinkman UAT, Cofino WP (1995) Survey of nine organotin compounds in The Netherlands using the zebra mussel (Dreissena polymorpha) as biomonitor. Environ Toxicol Chem 14:2023-2032

Stäb JA, Traas TP, Stroomberg (i, van Kesteren J, Leonards P, van Hattum B, Brinkman UAT, Cofino WP (1996) Determination of organotin compounds in the foodweb of a shallow freshwater lake in the Netherlands. Arch Environ Contam Toxicol 31:319-328

Stewart $C$ ( 1996$)$ The efficacy of jegisiation in controling tributyltin in the marine environment. In: de Mora SJ (ed) Tributyltin: case study of an environmental contaminant. Cambridge University Press, Cambridge, p 264-297

Stroben E, Oehlmann J, Schulte-OehImann U, Fioroni $P$ (1996) Seasonal variations in the genital ducts of normal and imposex-affected prosobranchs and its influence on biomonitoring indices. Malacol Rev Suppl 6 (Mollusc Reprod):173-184

Svavarsson J, Skarphedinsdottir H (1995) Imposex in the dogwhelk Nucella lapillus (L) in Icelandic waters. Sarsia 80: $35-40$

Szpunar J, Schmitt VO, Lobinski R (1996) Rapid speciation of butyltin compounds in sediments and biomaterials by CGC-MIP-AES after microwave-assisted leaching/digestion. J Anal Atomic Spectr 11:193-199

Ten Hallers-Tjabbes CC, Kemp JF, Boon JP (1994) Imposex in whelks (Buccinum undatum) from the open North Sea: relation to shipping traffic intensities. Mar Pollut Bull 28: $311-313$

Tenore KR and 18 co-authors (1995) Fisheries and oceanography off Galicia, NW Spain: mesoscale spatial and temporal changes in physical processes and resultant patterns of biological productivity. J Geophys Res 100:10943-10966

Tester M, Ellis D (1995) TBT controls and the recovery of whelks from imposex. Mar Pollut Bull 30:90-91

Tolosa I, Merlini L, De Bertrand N, Bayona JM, Albaiges J (1992) Occurrence and fate of tributyl- and triphenyltin compounds in Western Mediterranean coastal enclosures. Environ Toxicol Chem 11:145-155

Tolosa I, Readman JW, Blaevoet A, Ghilini S, Bartocci J, Horvat $M$ (1996) Contamination of Mediterranean (Cote d'Azur) coastal waters by organotins and Irgarol 1051 used in antifouling paints. Mar Pollut Bull 32:335-341

Vales R (1996) A sea of holidays. La Voz de Galicia 3/VIII/96: 88 (in Spanish)

Yamada $\mathrm{H}$, Takayanagi $\mathrm{K}$, Tateishi $\mathrm{M}$, Tagata $\mathrm{H}$, Ikeda $\mathrm{K}$ (1997) Organotin compounds and PCBs of livers in squid collected from coastal waters and open oceans. Environ Pollut 96:217-226 